\title{
Biodiesel and green diesel generation: an overview
}

Palani Vignesh ${ }^{1, *}$, Arockiyasamy Remigious Pradeep Kumar ${ }^{2}$, Narayanan Shankar Ganesh ${ }^{3}$, Veerasundaram Jayaseelan ${ }^{4}$, and Kumarasamy Sudhakar ${ }^{5,6}$

${ }^{1}$ Department of Mechanical Engineering, Indira Institute of Engineering and Technology, 631203 Tiruvallur, India

${ }^{2}$ Department of Mechanical Engineering, Dhanalakshmi College of Engineering, 601301 Chennai, India

${ }^{3}$ Department of Mechanical Engineering, Kingston Engineering College, 632059 Vellore, India

${ }^{4}$ Department of Mechanical Engineering, Prathyusha Engineering College, 602025 Chennai, India

${ }^{5}$ Faculty of Mechanical and Automotive Engineering Technology, Universiti Malaysia Pahang, 26600 Pekan, Pahang, Malaysia

${ }^{6}$ Automotive Engineering Centre, Universiti Malaysia Pahang, 26600 Pekan, Pahang, Malaysia

Received: 8 August 2020 / Accepted: 3 November 2020

\begin{abstract}
First, second, third, and fourth-generation biofuels are continuously evolving as a promising substitute to petrodiesel catalyzed by energy depletion, economic and environmental considerations. Bio-diesel can be synthesized from various biomass sources, which are commonly divided into FAME and renewable biodiesel. FAME biodiesel is generally produced by the transesterification of vegetable oils and fats while renewable diesel is produced by hydro-deoxygenation of vegetable and waste oils and fats. The different generation, processing technologies and standards for FAME and renewable biodiesel are reviewed. Finally, the life cycle analysis and production cost of conventional and renewable biodiesel are described.
\end{abstract}

\section{Introduction}

Unstoppable growth in the global population is estimated to hit 12 billion by 2030 , which would increase the annual energy needs of the resource limited countries [1]. Energy demand in developing countries is expected to rise by $90 \%$, and approximately one-third of this energy would come from renewable sources, such as biofuels.

Biofuel from harvested biomass is considered as the only available alternative to fossil fuels worldwide. Figure 1 represents the evolution of biodiesel [2].

Biofuels are categorized into four different generations based on their biomass feedstock. This sequence of developments of biodiesel ranges from the processing of edible oils until genetic modification of algae. Food sources are essential feedstock for first-generation biofuels and can also contribute to the competition of food [3]. While only $5 \%$ of the world's arable land is used to produce renewable resources in the form of first-generation biofuels, it has made a substantial impact on higher food and feed prices [4]. However, the existing effects of biofuels on the increase in food price remain uncertain in research or news reports. Biofuels produced from food and plantation waste, or non-food crops could solve the crisis [5]. Although the concept of first-generation biofuels had long emerged, it received considerable interest in the late 1990s.

\footnotetext{
* Corresponding author: vickymechleopard@gmail.com
}

Biofuels from second-generation lignocellulosic biomass, such as waste straw, grass and wood also require land with food and fibre processing compounds. However, energy returns from these crops are more favourable than firstgeneration biofuels or their products [6]. The search for alternative sources has continued to reduce competition in food crops to the extent that algae are used as a renewable and rich supply of biofuels known as third-generation biofuels [7]. Algae are not in a competitive environment with food or other crops and may be planted in shallow lagoons on marginal land or in enclosed wetlands [8].

Besides, algal biofuel feedstocks may be produced throughout the year unless there is a decrease in the availability of solar irradiation. The oil yields may be much higher than those of the best oilseed crops. For example, compared to neem, karanja, pine and eucalyptus, algae biodiesel contains $45 \%$ oil by weight which is significantly higher [9]. However, biofuels from the above sources are limited in geographical distribution; therefore, their carbon impact and economic aspects, are ineffective in replacing fossil fuels [10]. Table 1 shows the advantages and disadvantages of various biodiesel generations.

Fourth generation biofuel research has been carried out between 2000 and 2020 [11]. It is clear from the published research papers that the third-generation biofuels have received the highest emphasis in the last three years [12]. 


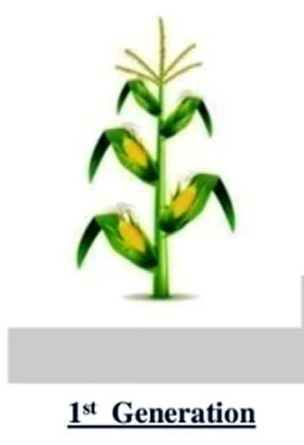

Edible Biomass

\section{Corn \\ 2. Sugar beet \\ 3. Wheat}

4. Rice bran

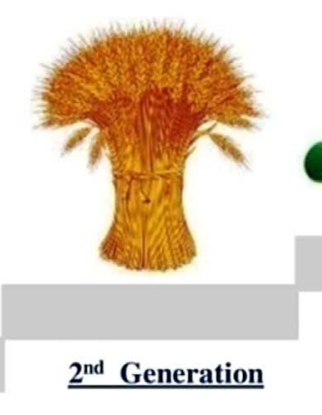

Non-Edible Biomass
1. Waste
2. Straw
3. Grass
4. Wood

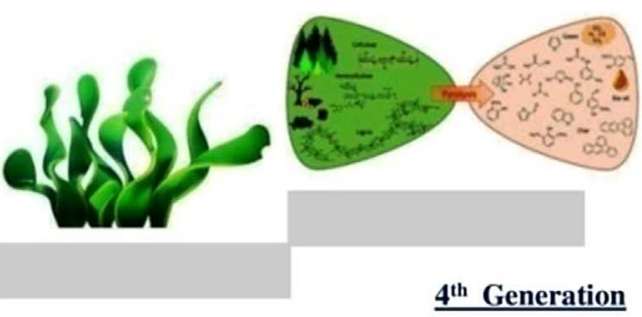

$\underline{3^{\text {rd }} \text { Generation }}$

Algal Biomass

1. Macro algae

2. Micro algae

\section{Chemical Processing}

1. Pyrolysis

2. Solar fuels

3. Genetic algae

4. Gasification

Fig. 1. Evolution of biodiesel [3].

Table 1. Advantages and disadvantages of various biodiesel generations [12].

\begin{tabular}{|c|c|c|}
\hline Biodiesel generation & Advantages & Disadvantages \\
\hline 1st generation biodiesel & $\begin{array}{l}\text { 1. Low emission of greenhouse gas. } \\
2 \text {. Easy and low-cost technology } \\
\text { for conversion. }\end{array}$ & $\begin{array}{l}\text { 1. Yield is inadequate to meet the } \\
\text { demand. } \\
\text { 2. Causes food shortage. } \\
\text { 3. High land footprint. }\end{array}$ \\
\hline 2nd generation biodiesel & $\begin{array}{l}\text { 1. Using food waste as a feedstock. } \\
\text { 2. Use of non-agricultural land to } \\
\text { grow a limited amount of crops. }\end{array}$ & $\begin{array}{l}\text { 1. Costly pre-treatment. } \\
\text { 2. Sophisticated technology is used to } \\
\text { transform biomass into fuel. }\end{array}$ \\
\hline 3rd generation biodiesel & $\begin{array}{l}\text { 1. Simple to grow algae. } \\
\text { 2. No competition for the use of food } \\
\text { crops: wastewater, seawater can } \\
\text { be used. }\end{array}$ & $\begin{array}{l}\text { 1. More resources usage for algae } \\
\text { cultivation. } \\
\text { 2. Low lipid level or biomass } \\
\text { accumulation in algae. }\end{array}$ \\
\hline 4th generation biodiesel & $\begin{array}{l}\text { 1. High biomass and production } \\
\text { yield. } \\
\text { 2. More capability to eliminate } \mathrm{CO}_{2} \text {. }\end{array}$ & $\begin{array}{l}\text { 1. The cost of the bio-reactor is higher. } \\
\text { 2. At the early stage of research, the } \\
\text { high investment needed. }\end{array}$ \\
\hline
\end{tabular}

\section{Biodiesel production/processing techniques}

The following section discusses the various biomass feedstocks and their suitability as substitutes for fossil fuels [13]. Table 2 shows the different processing method for various biofuel generation.

\subsection{First-generation biofuel - production}

As indicated above, first-generation biofuel feedstocks consist primarily of oleaginous, sugar cane and other food and animal source [14]. Bioethanol of the first generation is derived primarily from sugar, which includes plants or cereals. At present, the maximum quantity of biofuel in the form of ethanol has been produced, of which $92 \%$ is from corn and sugar cane [15]. Approximately $15 \%(\mathrm{v} / \mathrm{v})$ of crude corn ethanol with fungal and algae mutants has been studied. The development of sugar cane ethanol is currently at different stages of maturity [16]. Greater yields of ethanol after 300-325 days of planting are also realised. Vegetable oils are often used for the conversion of methyl or ethyl fatty acid esters [17, 18]. Table 3 and Figure 2 represent the processing methods of firstgeneration biodiesel. 
Table 2. Various generations of biofuel with processing technology.

\begin{tabular}{|c|c|c|c|c|}
\hline Generation & Biomass used & Processing methodology & Generated fuel & Ref. \\
\hline $1 \mathrm{st}$ & $\begin{array}{l}\text { Food crops, edible } \\
\text { oil/animal fats }\end{array}$ & $\begin{array}{l}\text { Transesterification - } \\
\text { Thermochemical processing }\end{array}$ & Bioethanol, biodiesel. & {$[16,18]$} \\
\hline 2nd & $\begin{array}{l}\text { Waste cooking oil, } \\
\text { rice/wheat straw, } \\
\text { non-edible oils }\end{array}$ & $\begin{array}{l}\text { Pre-treatment - Chemical, } \\
\text { biological, physical, fermentation } \\
\text { and thermochemical processing }\end{array}$ & $\begin{array}{l}\text { Syngas, biobutanol, } \\
\text { biodiesel. }\end{array}$ & {$[23,27]$} \\
\hline $3 \mathrm{rd}$ & $\begin{array}{l}\text { Algae and } \\
\text { microorganisms }\end{array}$ & $\begin{array}{l}\text { Cultivation - Extraction - } \\
\text { Fermentation - Thermochemical } \\
\text { processing }\end{array}$ & $\begin{array}{l}\text { Methane, bioethanol, } \\
\text { biobutanol, syngas, } \\
\text { biodiesel. }\end{array}$ & {$[33,34,39]$} \\
\hline 4 th & $\begin{array}{l}\text { Algae and } \\
\text { microorganisms }\end{array}$ & $\begin{array}{l}\text { Metabolic engineering of algae } \\
\text { capable of absorbing biomass - } \\
\text { Cultivating - Fermentation - } \\
\text { Thermochemical processing }\end{array}$ & $\begin{array}{l}\text { Biodiesel, methane, } \\
\text { biobutanol, bioethanol. }\end{array}$ & {$[45-47]$} \\
\hline
\end{tabular}

Table 3. First generation biofuels.

\begin{tabular}{lcc}
\hline Biomass & Processing method & Ref. \\
\hline Waste cooking oil & Esterification - Transesterification & {$[16]$} \\
Food crops & Extraction - Transesterification & {$[17]$} \\
Organic oils & Hydrolysis - Distillation & {$[18]$} \\
Animal fat & Hydrolysis - Fermentation & {$[19]$} \\
Bioethanol/biobutanol & Chemical synthesis & {$[20]$} \\
\hline
\end{tabular}

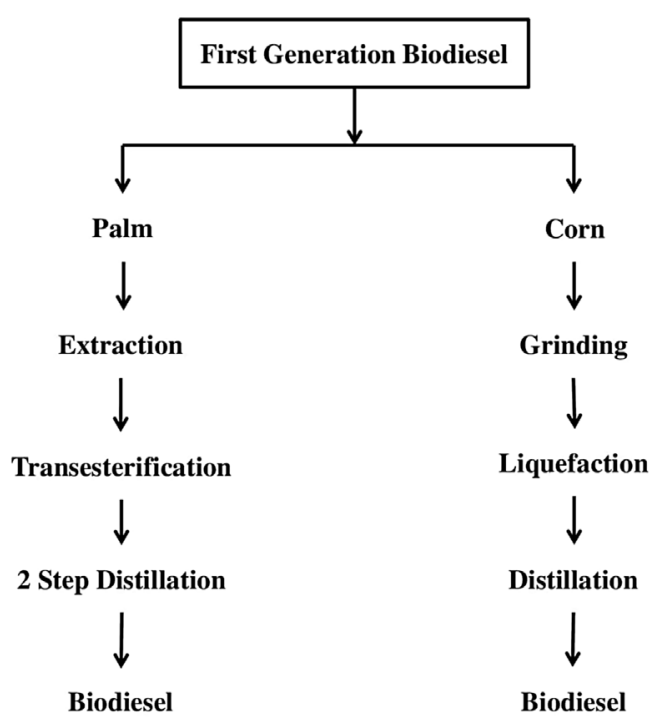

Fig. 2. First-generation biodiesel processing [19].

An experiment on cottonseed oil produced $63.4 \%$ biodiesel with $35 \%$ methane in the presence of $2.6 \%$ sodium hydroxide. Reduction of carbon monoxide, particulate matter and exhaust soot emissions have been observed for all biodiesel mixtures [19]. A small increase in $\mathrm{NO}_{\mathrm{x}}$ emissions was reported for Karanja biodiesel mixtures. Attempts have been made to test the performance of organic oils, particularly in diesel engines. However, organic oils were not considered suitable, leaving wax and fluid deposits in engines [20]. Organic sludge, which is produced from the agricultural waste, may be another promising source of biofuel. The cracking response of vegetable oil results in products similar to syngas, liquefied-oil, diesel, light-cycle oil and heavy-cycle oil cracking processes [21].

\subsection{Second-generation biofuel - production}

Approximately $90 \%$ expense of biodiesel production is met from the selected feedstock. The production of lowcost bioethanol from trees, forest residues, wood waste and the organic portion of urban waste is known as secondgeneration biofuels [22]. With due recognition to its high-octane number, low cetane number and high vaporisation heat, it is capable of replacing gasoline [23]. The production of bioethanol using these materials would no longer need land and would thus have no impact on the production of food and fibre crops. Lignocellulose biomass is plentiful in nature, but only a small part of it can be used. Theoretically, these biomass sources will supply 130 EJ of electricity annually [24].

With all species, such as Southern Blue Gum, Salicaceae and Black Locust, grasses such as Silver Grass and Panicum virgatum are becoming increasingly common as they can be cultivated in fertile and degraded land that is not usually suitable for food production and fibre cultivation [24]. The production of ethanol by fermentation from a separate pre-treated cellulose fraction of corn cob with 
Table 4. Second generation biofuels.

\begin{tabular}{lcc}
\hline Biomass & Processing method & Ref. \\
\hline Cellulose & Advanced fermentation & {$[22]$} \\
Hemicelluloses & Hydrolysis & {$[26]$} \\
Lignin & Gasification & {$[27]$} \\
Tannins & Biological synthesis & {$[28]$} \\
Vegetable oil/animal fat & Hydrogenation & {$[31]$} \\
\hline
\end{tabular}

Pachysolen tannophilus and yeast was studied [25]. It was found that $60-90 \%$ of hemicellulose and $52-70 \%$ of cellulose could be converted into ethanol by different fractionation processes in corn cobs [26]. Recently, the use of ceibapentandra, pineapple, waste paper and coffee residues has been listed for the production of bioethanol. The processing of bioethanol from waste materials can also be combined with the production of biogas [27].

Biodiesel from raw Jatropha and Karanja oils can be blended with diesel for applications in engines [28]. The biogas is produced from de-oiled neem and pine seedcake. Genetic engineering can be a valuable tool for producing fast-growing low-input energy crops with lower insecticide, fertiliser and water requirements in order to minimise overall biofuel costs [29]. Genetically modified wheat and barley have been found to have hydrolyzed biomass without compromising its composition and losing agricultural productivity [30]. Table 4 and Figure 3 represent the processing methods of second generation biodiesel.

Advanced biofuels such as isopropanol, butane, isobutane and farnesol have recently become more desirable in addition to ethanol due to high energy density and hygroscopic nature [31]. Biochemical engineering of biosynthetic pathways leading to the production of alcohol will boost efficiency [32]. Aldehyde/alcohol dehydrogenase expressions in Clostridium tyrobutyricum increased butanol production by approximately $25-35 \%$, but also increased its resistance to butanol [33]. Changing the mechanism of amino acid biosynthesis in E. coli resulted in an increased development of 1-butanol and 1-propanol.

\subsection{Third and fourth generation biofuel - production}

Due to their increased photosynthesis and rapid growth, algae have recently had a major interest in renewable biofuel feedstock compared to other terrestrial plants [34]. On a dry weight basis, algae can generate up to $64 \%$ lipid and can grow on a liquid medium from multiple wastewater sources, resulting in lower demand for freshwater [35]. Recent research efforts have focused on finding the best combination of high lipid and optimum algal organism growth conditions [36]. Several algae species, such as Trebouxiophyceae, Chaetocerotaceae, numerous single-cell green algae, Haptophyta, Eustigmatophyceae, Aurantiochytrium limacinum and Scenedesmaceae, have been identified as potential biofuels [37]. The highest average lipid and biomass content of chlorophytes was obtained, but the triglyceride content was low. As an alternative, some algal species can produce 10-50\% triglycerides, $25-65 \%$
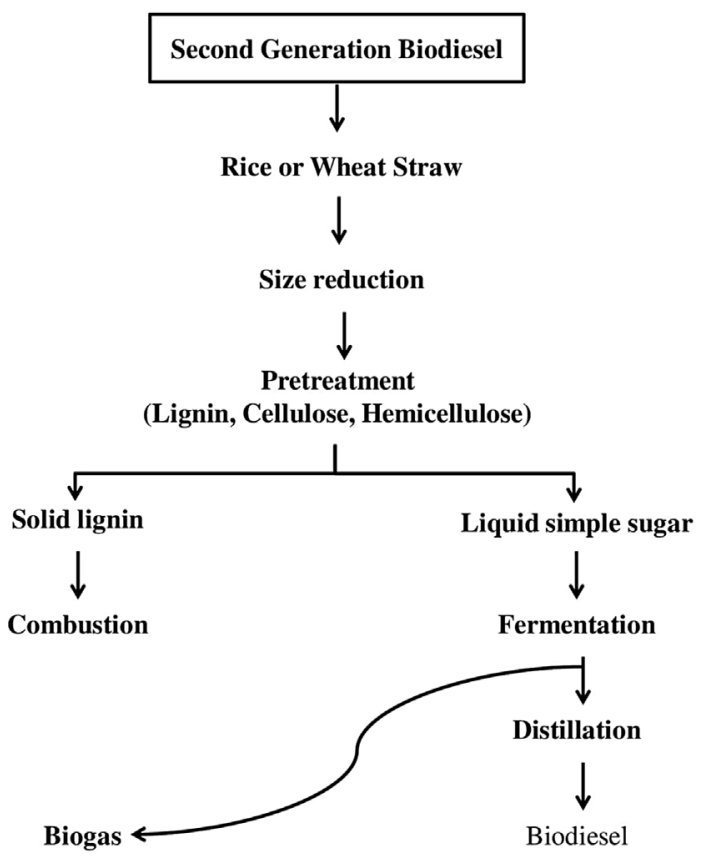

Fig. 3. Second-generation biodiesel processing [25].

and 40-80\%, respectively, of dry cell weight, such as Botryococcaceae, Ochrophyta and Thraustochytrids, although biomass yields are low in each case [38].

Fast-growing algae are generally found to have low oil content, whereas high lipid algae are slow-growing species. It is, therefore, essential to identify the correct species with high biomass and high lipid concentrations for the marketing of algal biofuels [39]. Biomass and lipid yield of the same strain of microalgae are also affected by the cultivation process. In this context, genetic modification/metabolic engineering may be promising alternatives to the production of lipid levels and algal biomass [40]. Researchers are searching for an acceptable method of culture to increase lipid content and make it more cost-effective and sustainable. Failure to activate ADP-glucose pyrophosphorylase in a pseudomonas starch-free mutant resulted in triacylglycerol being 10 times higher, indicating that sharing of photosynthetic carbon partition from starch to triacylglycerol synthesis may be more successful than lipid synthesis pathway manipulation against triacylglycerol overproduction [41]. The Synechococcus elongatus is capable of producing butanol directly from $\mathrm{CO}_{2}$ by altering the coA-dependent 1-butanol process pathway to cyanobacterium [42, 43]. Figure 4 represents the processing methods of third/fourth generation biodiesel [44].

\section{Hydrogenated Vegetable Oil - production}

Renewable diesel is derived by refining organic oil/animal fat, extracted in a procedure termed as hydro-treatment of fatty acids. In comparison to the glycerin-based esterification reaction of organic oils/animal fats, the diesel produced in this step is known as renewable diesel in order 


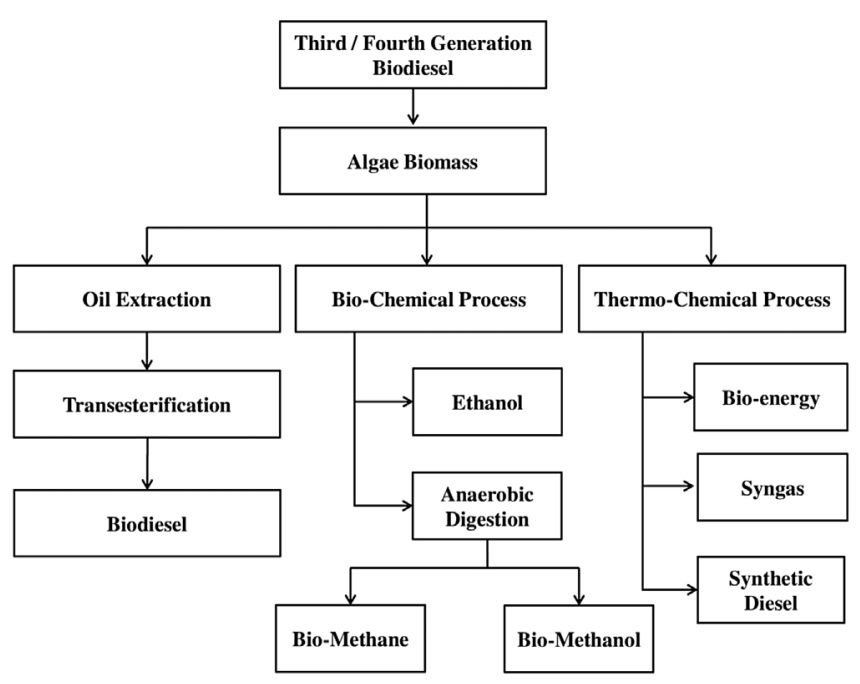

Fig. 4. Third/fourth generation biodiesel processing [36].

to differentiate it from conventional biodiesel [45]. Sustainable diesel is generally referred to as "green diesel", and can be extracted from fatty acids or vegetable oils using conventional hydro-treatment technology [46]. Any biodiesel or green diesel may be similar to the original biomass oils. Hydro-treated oil is a high-quality, sulphur-free diesel with a very large proportion of Cetane 88-95 [47]. As glycerine is a co-product of the latter process, the net yield of hydrolysed organic oils is much higher than that of the esterification reaction. Oil refiners use hydrolysis to eliminate impurities through the treatment of gaseous hydrogen feed [48]. Conversion temperatures ranging from $800{ }^{\circ} \mathrm{C}$ to $950{ }^{\circ} \mathrm{C}$ and pressures ranging from 30 to $90 \mathrm{~atm}$ are included in hydro-processing and reaction times ranging from 15 to $80 \mathrm{~min}$. Some chemical reactions are improved by the use of solid catalysts, product selectivity is improved and total hydrogen consumption is optimised [49].

Hydrolysis process involves heat and pressure and ultimately reduces the molecular weight of the feed [50]. In triglyceride-containing oils, four hydrocarbon molecules, for example, are reduced by propane molecules and three hydrocarbon molecules under hydrotreatment [51] in the range $\mathrm{C} 12-\mathrm{C} 18$. Green diesel processing includes the hydrogenation of triglycerides for the removal of metals, oxygen and nitrogen compounds by the current refinery [52]. These diesels which can be used for production by dedicated hydro-treatment plants do not use conventional fuel. As a result, the investment cost of developing this renewable diesel is relatively lower than the process of transesterification that produces biodiesel [53].

Renewable fuel may be used as a partial solution or combination with any percentage of petroleum-based diesels, without altering the engines or vehicle fuel tank design [54]. The low carbon intensity of renewable diesel produced from organic waste oils/animal fats is also attributed to the enhanced fuel quality [55]. The simplest form of hydrocarbon molecules with combination of straight chain and branched paraffin in renewable diesel, is considered to be safe fuel based on complete combustion perspective.
Standard carbon numbers are $\mathrm{C} 12-\mathrm{C} 18$ [56]. Paraffin, which contains a large amount of aromatic and naphthenic substances, is often present in diesel oil. Aromatic materials are not ideal for safe combustion and those organic hydrotreated oils/fats are scarce [57]. The EN 14214 petrol diesel fuel standard is suitable for different types of diesel engines. This specification has seven different grades and No. 2D complies with sustainable diesel, the objective of which is to use diesel in low-sulphur applications that are ideal for varying speeds and load conditions [58]. Figure 5 provides a comparison of FAME and Hydrogenated Vegetable Oil (HVO) processing technique.

\section{Difference between biodiesel and Hydrogenated Vegetable Oil}

Biodiesel is a mono-alkyl ester produced from the longchain, carbonic fatty acid. It is formed by transesterification of oil-rich fats or biomass. It is possible to convert triglycerides to esters with more gasoline-like properties [59]. Triglycerides react with alcohol, such as methanol and ethanol, in the presence of alkaline catalyst, such as potassium hydroxide and at certain temperatures [60]. It produces methyl or ethyl esters and is a co-product of glycerine. Table 5 shows the comparison between FAME and HVO.

Renewable diesel is a similar process, except that vegetable oil is processed at high pressure and high temperature in the presence of hydrogen and strong catalyst [61]. As a simple and vibrant fuel called green diesel, propane, $\mathrm{CO}$ or $\mathrm{CO}_{2}$, vegetable oil or/and animal fat is converted to diesel. This process can also be carried out with any crude oil. Palm oil, pine oil, potato oil, corn oil is the most common vegetable oil [62]. However, renewable diesel can be generated from a broader variety of feed stocks than biodiesel. Two key reasons why this is supported are as follows:

- The level of unsaturation of feedstock molecules is not considered as the effects as hydrotreatment result in fully saturated paraffin hydrocarbons that are not sensitive to oxidative instability throughout the biodiesel containment of unsaturated methyl esters [63]. Thus, the production of Hydrogenated Vegetable Oil does not rely on the free fatty acids of the feedstock [64].

\section{Properties and standards of bio-fuel}

\subsection{Properties and standards of conventional biodiesel (FAME)}

Some of the key physical/chemical characteristics of biodiesel (FAME) extracted from the six feedstocks are detailed in Table 6 . The fatty acid methy esters are tested based on ASTM standards [65]. Multiple studies argued that the prices of FAME are very different. This variation in properties, as with the fatty acid profiles, is primarily due 


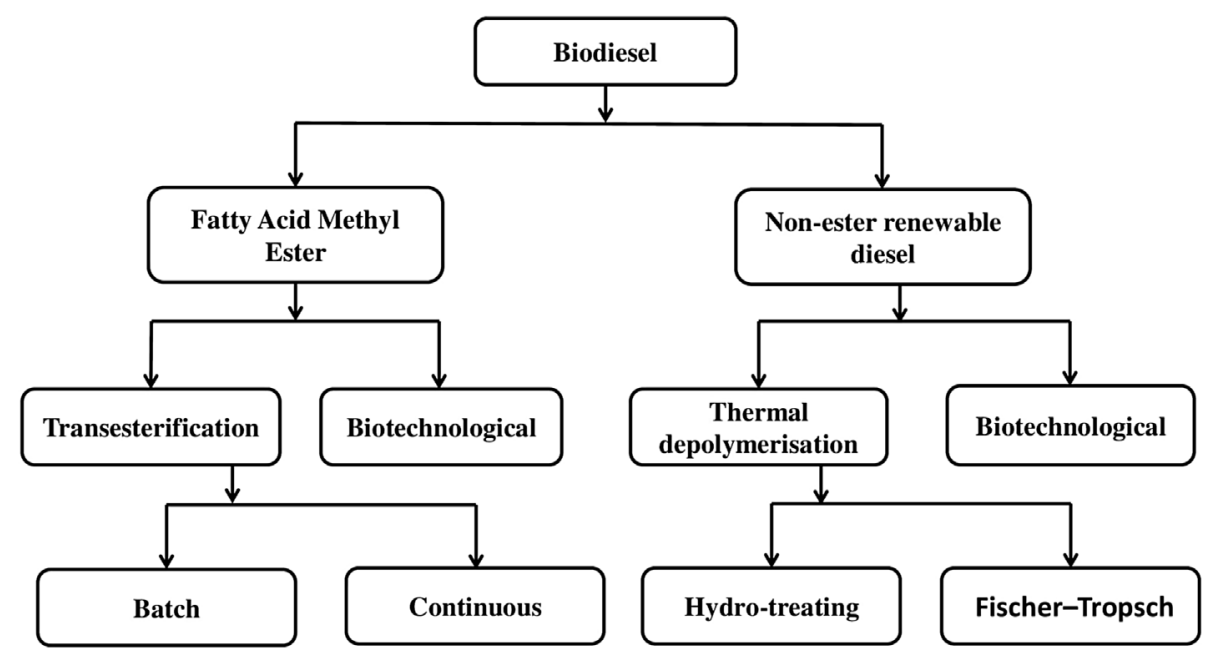

Fig. 5. FAME and HVO processing comparison [52].

Table 5. Comparison between FAME and HVO [60].

\begin{tabular}{lcc}
\hline Properties & FAME & HVO \\
\hline Feedstock & Food corps, seeds and non-edible oils & Vegetable oil/animal fats \\
Catalyst & Ethanol, methanol & Hydrogen \\
By products & Glycerol, wax, soap & Water \\
$\mathrm{NO}_{\mathrm{x}}$ pollutants & Emission increased to $15 \%$ & Emission decreased \\
$\mathrm{CO}_{2}$ contaminates & $20-32 \%$ ppm & $12-15 \% \mathrm{ppm}$ \\
\hline
\end{tabular}

to the use of various analytical techniques and varying degrees of performance. [66]. All sources of uncertainty are the chemical method used for the production of FAME, the cleaning and washing process used for raw FAME and the storage period prior to the testing [67].

The oxidation stability of FAME is a key property of biodiesel, but this review has not been taken into account, as the cleaning and storage activities of FAME strongly influence the same [68]. In addition, some of the biodiesel samples included antioxidant additives which had altered the inherent stability of FAME. There are some other FAME for which standards have been developed, but which also rely mainly on production and handling practises and not on FAME itself [69]. These include water, sediment, methanol content, ash, metal, acid count, glycerin and cold soak filtering.

The method used to evaluate the biodiesel properties reported in the literature was close to that used for the above fuel [70]. Initially, without a prior judgement on the validity of the data, all recorded values were recognised. The mean and standard deviations for each FAME are determined from this raw data [71]. Careful inspections were then carried out, in particular for values which varied significantly from the average. In some cases, viscosity values have been observed to be measured at temperatures other than the $40{ }^{\circ} \mathrm{C}$ standard [72]. Since the viscosity varies significantly with the temperature, the non-normal temperature values have been omitted when deciding the mean and standard deviations [73]. Energy quality is another important FAME property, as no requirements are set for this by the U.S. and European biodiesel standards [74]. However, several authors have recorded energy content values, but the measurements used are very contradictory. For example, lower heating, higher heating value, gross energy content and net energy content were all noted, usually without specific measurements [75]. Some sources have not suggested the exact metric. In these cases, the authors' opinion credited values either to a lower heating value or to a higher heating value.

\subsection{European standards of conventional biodiesel (FAME)}

The biodiesel properties shown in Table 7 have been determined on the basis of the FAME types:

- Average chain length.

- Average unsaturation.

The average chain length was determined by multiplying the mass fraction of the FA portion by the corresponding carbon number, and then adding the entire component [76]. Similarly, the mean degree of unsaturation was determined and summarised by multiplying the corresponding amount of carbon double bonds by the mass fraction of each FA component [77]. 
Table 6. Properties of various FAME biodiesel [67].

\begin{tabular}{lcccccc}
\hline Properties & Corn & Neem & Palm & Sunflower & Rapeseed & Pine \\
\hline Specific gravity & 0.881 & 0.001 & 0.874 & 0.016 & 0.003 & 0.007 \\
Cloud point, ${ }^{\circ} \mathrm{C}$ & -2 & 3.3 & 5 & 4 & -1 & 13 \\
Flash point, ${ }^{\circ} \mathrm{C}$ & 124 & 143 & 122 & 114 & 136 & 159 \\
Cetane value & 50.4 & 33.8 & 58.9 & 53.8 & 51.8 & 49.6 \\
CFPP,${ }^{\circ} \mathrm{C}$ & 13 & 2 & -1 & 6 & 8 & -3 \\
Kinematic viscosity, $\mathrm{mm}^{2} / \mathrm{s}$ & 1.60 & 3.78 & 0.56 & 4.45 & 0.23 & 3.87 \\
Pour point, ${ }^{\circ} \mathrm{C}$ & 3 & -6 & 4 & 2 & 10 & 3 \\
Sulfur, ppm & 1 & 3 & 8 & 4 & 6 & 5 \\
\hline
\end{tabular}

Table 7. FAME biodiesel European standard [75].

\begin{tabular}{lcccc}
\hline Properties & \multicolumn{2}{c}{ EN 590:2004 } & EN 14214:2012 \\
\hline Density, $\mathrm{kg} / \mathrm{m}^{3}$ & $815-834$ & EN ISO 3575 & $850-890$ & EN ISO 12183 \\
Total contamination, $\mathrm{mg} / \mathrm{kg}$ & 30 & EN ISO 12668 & 30 & EN ISO 12673 \\
Flash point, ${ }^{\circ} \mathrm{C}$ & 58 & EN ISO 12716 & 106 & EN ISO 12718 \\
Cetane value & 51.5 & EN ISO 5163 & 52.6 & EN ISO 5167 \\
$\mathrm{CFPP},{ }^{\circ} \mathrm{C}$ & 13 & EN ISO 112 & 18 & EN ISO 119 \\
Kinematic viscosity, $\mathrm{mm}^{2} / \mathrm{s}$ & $1.0-3.2$ & EN ISO 3206 & $3.6-5.3$ & EN ISO 3209 \\
Water, $\mathrm{mg} / \mathrm{kg}$ & 250 & EN ISO 13024 & 500 & EN ISO 13706 \\
Sulfur, $\mathrm{mg} / \mathrm{kg}$ & $10-50$ & EN ISO 8763 & $10-12$ & EN ISO 20831 \\
\hline
\end{tabular}

Biodiesel properties can differ considerably from one feedstock to another [78]. However, the characteristics of conventional diesel are also useful for a brief comparison of some critical properties of biodiesel fuels as shown in Table 7.

\subsection{Properties and standards of Hydrogenated Vegetable Oil}

Renewable diesel is as clear and bright as water with high heating value. The energy content of renewable diesel is higher than that of biodiesel in $\mathrm{MJ} / \mathrm{kg}$, i.e. the mass and volume required to meet the test specifications of renewable diesel [79]. Low sulphur and metal-free content make it suitable for various applications. The impurity that causes precipitation over the cloud point makes it a clear fuel. The aromatic linearity makes it almost equivalent to the stability of diesel oil [80]. The renewable diesel is similar to diesel water solubility and the sustainability of the fuel is not the major concern [81]. The cloud point is less than $-40{ }^{\circ} \mathrm{C}$ for renewable diesel, which provides a high mixing order throughout the year, except in winter. Density also remains almost constant at a low cloud point [82].

As with conventional bio-diesel, some precipitation of paraffins from the renewable diesel may take place if the temperature is below cloud point for a long period. It is recommended to store all diesel fuels above cloud point [83]. Due to the influence of high cetane and low density, CI engines are more widely used. The Cetane index also shows a linear increase with the mixing ratio [84]. Mixing of medium HVO concentrations of more than $60 \%$ affects the cetane number of fuel. Direct blending limitations could not be applied to other fuel properties such as density, viscosity, the concentration of water. In contrast, reductions in density may result in some fuel savings and flexibility in the refinery process [85]. They are safe for storage and transport as renewable diesel flash points are above diesel. There is no microbial development of renewable diesel [86]. They can be combined with diesel fuel in refining or/during fuelling. Green diesel and diesel oil are highly compatible [87].

Without impacting fuel processing, engines and exhaust emissions, treatment of vegetable oil is a new way of producing high-quality bio-based diesel fuel. Instead of "biodiesel" reserved for fatty acid methyl esters, these oils are often referred to as "renewable fuel" [88]. Vegetable oils that are chemically hydrolyzed are paraffin hydrocarbon blends that are free from sulphur and fragrance. By changing the process intensity or further catalytic processing, the cold characteristics of HVO may be modified in accordance with local specifications [89]. The amount of Cetane is very high and the other properties of liquid and biomastic-liquid diesel fuel are very similar to Fischer-Tropsch synthesis gas. Table 8 shows the properties of Hydrogenated Vegetable Oil.

As HVOs are hydrocarbons, they comply with conventional diesel fuel requirements (EN 590), with the exception of a low-density value. The criteria of FAME ester (EN 14214) do not refer to HVO [90]. The lower heat output of HVO is significantly higher than ethanol. One litre or 
Table 8. Hydrogenated Vegetable Oil properties [80].

\begin{tabular}{lc}
\hline Properties & Hydrogenated Vegetable Oil \\
\hline Density, g/mL & 0.852 \\
Oxidation stability, hr & $>25$ \\
Net heat value, MJ $/ \mathrm{kg}$ & 55 \\
Viscosity, cSt & 6.5 \\
Flash point, ${ }^{\circ} \mathrm{C}$ & 125 \\
Nitrogen, $\mathrm{mg} / \mathrm{kg}$ & 2.6 \\
Sulfur, $\mathrm{mg} / \mathrm{kg}$ & 3.5 \\
Cetane index & 82 \\
\hline
\end{tabular}

one gallon of HVO will drive the vehicle almost twice as long as ethanol-based fuel, such as E60, compared to spark ignition engines, where greater efficiency is also considered [91].

When examining the properties of biodiesel extracted from different feedstocks, it is necessary to take into account the essential requirements laid down by the various organisations of the basic fuel institutions, in particular the European Committee for Standardization (CEN) [92]. At present, only the B100 standard, EN 14214, has been established by CEN, but not for mixtures such as B50. Mixtures of B15 and below are permitted under the European Standard Conditions for conventional diesel fuel (EN 275) and negotiations are on-going to increase the volume of B20 [93].

\section{Environmental impact of biofuels}

Emissions of GreenHouse Gases (GHG) from biofuels depend not only on the gas produced by the combustion of carbon but also on the combined impact of GHG emissions during the various stages of supply, such as biomass processing, transport to the industrial conversion unit and distribution [94]. $\mathrm{CO}_{2}, \mathrm{CH}_{4}$ and $\mathrm{N}_{2} \mathrm{O}$, are three essential GHGs rendered into $\mathrm{CO}_{2}$ equivalents of Global Warming Potential (GWP) proposed by the Intergovernmental Commission on Climate Change, are researched in recent years. Net fossil fuel GHG emissions include refining/ extraction, transport, conversion, storage and end-use pollution [95].

\subsection{Impact on land usage}

Direct and indirect land use and biomass improvements are well considered in terms of GHG emissions. As bio-energy plants are grown on land previously abandoned for crop cultivation, a direct land-use change takes place [96]. This applies to grasslands, forests, soil or degraded soil. As the development of energy crops changes prior to land operation, indirect land-use changes occur [97]. The transition to land use is the most important one for the development of palm oil biodiesel for net GHG emissions, which could have been reduced by $80 \%$ if depleted soil could have been used instead of natural rainforest or converted to tourism
$[98,99]$. The land use change results in soil carbon sequestration to increase the mitigation of biofuel. Several studies have shown that, for several decades, converting cropland to grassland for grass cultivation usually raises soil carbon at a rate of $0.5-2.0 \mathrm{t}$ carbon/ha per year [100].

\subsection{Environmental concern}

In addition to the two main environmental issues referred to above, the production of biofuels will either directly or indirectly affect the supply of water and nutrients [101]. Biomass feedstock farming requires water and nutrients, regardless of the method of biofuel processing [102]. The use of sea water or wastewater for bio-mass cultivation may be a potential option instead of freshwater. Seawater is readily available, but its high salinity in a variety of species precludes its application [103]. Biofuel feedstocks of first and second generation in raw waste water are difficult to produce. However, as described above, with the use of nutrients in waste water and seawater, algae can grow, which reduces the need for freshwater [104]. Algae cultivation thus provides an optimised system for waste water or water use for the production of biofuels.

\subsection{Life Cycle Assessment of biodiesel}

Engines working with ethanol fuel emit less carbon monoxide than petrol engines. A number of studies have been conducted to reduce net GHG emissions from lignocellulosic ethanol relative to fossil fuels [105]. Authors reported a reduction of $40 \%$ and $80 \%$ in GHG emissions compared to petrol for E90-fuels derived from ethanol switchgrass and corn Stover ethanol, respectively [106]. The corn stovers had reduced GHG emissions by about 7 and 18 compared to natural gas and coal as a source of heat and energy [107]. Net emissions of GHGs vary by source of biofuel and are correlated with significant volumes of by-products produced during the processing of biofuels, which involves a Life-Cycle Assessment of the treatment of biofuels from multiple sources to quantify the net emissions of GHGs [108]. Biofuel co-products can be used in the Life Cycle Assessment (LCA). LCA analyses on lignocellulosic ethanol from switchgrass and corn stover in Canada have shown that corn stover are more desirable than switchgrass for net GHG emissions when using Cradle-to-Grave analysis for the processes [109]. Compared to ethanol derived from switchgrass, a saving of $40 \%$ of GHG emissions from starch-derived ethanol from corn was recorded. Many researchers noted that savings of $80-100 \%$ GHG emissions are possible with the use of ethanol compared to fossil-based gasoline. Table 9 represents Life Cycle Assessment of biodiesel [110].

In the proposed LCA model for the conversion of urban solid waste ethanol [111], the authors noted an $82 \%$ decrease in switchgrass GHG emissions, followed by hay $(75.2 \%)$, corn $(90 \%)$, wheat straw $(73 \%)$ and corn $(47 \%)$. The overall GHG emissions from the manufacture of process chemicals and enzymes used for the pre-treatment of lignocellulose biomass, including corneal ethanol GHG emissions, are estimated to be significantly lower than those 
Table 9. Life Cycle Assessment of biodiesel.

\begin{tabular}{lccr}
\hline Biofuel & Net energy ratio & The model used for calculation & Ref \\
\hline Fossil fuel & 6.3 & Energy life cycle analysis small farm production & {$[115]$} \\
Soybean biodiesel & 4.25 & Energy life cycle analysis small farm production & {$[116]$} \\
Palm biodiesel & $7.9-8.5$ & CED, PNAS & {$[118]$} \\
Pine biodiesel & 8.36 & Energy accounting method & {$[119]$} \\
Algae biodiesel & 5.58 & Biofuel analysis meta model & {$[120]$} \\
Rapeseed biodiesel & $6.71-7.2$ & Greet model & {$[122]$} \\
Corn biodiesel & $4.26-5.12$ & Energy and Resources Group & {$[124]$} \\
\hline
\end{tabular}

from the manufacture of corn ethanol and petrol/diesel emissions.

In the case of third and fourth generation biofuels, the reduction of GHG emissions can be achieved by recycling $\mathrm{CO}_{2}$ produced as a carbon source for the production of algae during the fermentation process [112]. The life cycle of the production of chlorellaceae biogas was investigated and compared with first-generation biodiesels. The high productivity of algae allowed the recycling of $\mathrm{CO}_{2}$ in flue gas [113]. Algae were also able to directly absorb and produce methane, and nutrients were also recycled [114]. Their findings have shown that the production of algae methane can directly mitigate the emissions, whereas further changes could be made by reducing the cost of mixing and by increasing the output of the anaerobic process under regulated conditions [115].

The proposed algal cultivation in conventional raceway ponds should be slightly more environmentally safe than fossil fuel, with a potential production target of 60 tonnes of lipids per year. Biodiesel from algae grown in raceway ponds was $70 \%$ lower than fossil fuel. Both algal processing stages had a significantly lower demand for fossil energy and GWP than the cultivation requirements [116].

\subsection{Life Cycle Assessment of Hydrogenated Vegetable Oil}

Traditionally, LCA has been used to identify the environmental hazards of a number of other biofuels, both diesel and petrol [117]. Three separate feedstocks were studied to assess the Life Cycle Assessment of HVO. The rapeseed oil methyl ester and wheat ethanol marginally enhanced performance in terms of global warming and eutrophication, but the same was true of potential photochemical ozone production and energy consumption. The greenhouse gas emissions and a wide range of environmental impacts with a combination of biofuels (methyl ester, ethanol, biogas, dimethyl ether, etc.) have been studied [118]. Methyl ester from waste cooking oil had low greenhouse gas emissions, but no analysis on acidification and eutrophication have been studied [119]. The life-cycle emission between petrol and E10 was very limited (10\% bioethanol and 90\% gasoline) in terms of greenhouse gases [120]. Several LCA studies on bio-based ethanol showed, favourable net energy output. Despite the results of several studies, it cannot be inferred that biofuels have a lower impact on the atmo- sphere than fossil fuels. The importance of integrating additional effects on LCA research, in addition to greenhouse gas emissions are also demonstrated [121-123]. The environmental effects of HVOs combustion in heavy vehicles in Europe, were analysed using LCA research. The standard unit was assumed as $1 \mathrm{kWh}$ from the heavy vehicle (kWh engine) [124]. For the production of HVO, vegetable oils may come from different biological sources. Rapeseed oil, palm oil, and jatropha oil were investigated. Rapeseed oil is expected to be a raw material for the production of HVO from European feedstock [125]. In reality, with the best prices per hectare, palm oil is the cheapest vegetable oil among all vegetable oil feedstocks. It is also currently used in the production of HVO by the Nest Oil feedstock [126]. Jatropha is a plant that is thought to thrive on wastelands and can also be used to replenish the soil. Malaysia's palm oil and India's Jatropha were considered in Germany in this analysis [127]. Hydrotreatment is required for all three feedstocks at the Neste Oil production facility in Greenland. The HVO is considered to be part of the diesel engines in Germany.

Electricity has been modelled as a specific source of electricity used in different countries, rather than as marginal electricity. In this article, all loads were considered using fossil diesel, not HVO or other non-fossil fuels [128]. Production capital, such as construction and transport vehicles, as well as the transport of workers to installations and electricity for offices, have been systematically omitted. Large-scale production has been assumed for all three oil plants [129]. Aspects relevant to land planning for agriculture are not covered. In this was partly due to well-defined methodological problems: the parameters to be considered and the methods to be applied are not stated. In addition to a study of other LCA reports, land use has been omitted [130].

The most important aspects of the biofuel evaluation are potential greenhouse gases and environmental pollution [131]. Global warming potential, acidification potential, eutrophication potential and embedded fossil energy production are the impact categories assessed in the report. Biofuels have emissions that contribute to acidification and eutrophication; input from the supply chain, for example in Rapeseed Methyl Ester, or RME and ethanol studies has shown a substantial effect on overall supply. Notice that the "pound" unit in this analysis also corresponds to the metric tonne, i.e. $1000 \mathrm{~kg}$. The sensitivity analysis 
investigated the effect of certain parameters on the biofuel which are increasingly common in LCA studies [132, 133].

\subsection{Economic assessment of biofuels}

Biofuel production costs include the cost of feedstock over time, plus the estimated conversion costs, including resource costs, chemicals and enzymes, electricity costs, operation and maintenance costs, minus the value of the co-product over time [134]. Except for sugar cane ethanol in Europe, the cost of production of all first-generation biofuels is essentially subsidised in all countries. In brief, higher food crop prices make biofuels of the first generation more competitive [135]. For some of its feedstock products, such as corn in European countries, the rapidly increasing demand for biofuel feedstocks has significantly increased prices. In this sense, biofuels are derived from low-cost feedstocks [136]. The minimum cost was estimated for corn ethanol, while the limit was estimated for algal biodiesel. The cost of capital per unit of production capacity decreases as the size of the plant increases for relatively large plants.

Generally speaking, the cost reduction is considered to be sufficient to cover the rising cost of biomass resulting from longer average transport distances associated with higher output sizes [137]. Developed economies are more serious in thermochemical processes, than biochemical conversions but in both situations, commercial development has to face challenges [138]. The economy of first-generation biofuels in Europe is more forward-looking than the exemption from excise duty under current political circumstances. Still, the critical problems of this generation of biofuels are a lack of feedstock land and moderate environmental efficiency. Industrial processing of first and second-generation biodiesel is carried out in several countries [139].

Biomass processing costs are dominant for both algae and rapeseed biodiesel. Important factors are the production of biomass from algae, the supply of carbon, the harvesting and the source of water [140]. While land costs are low for the development of algae biomass, there are higher infrastructure and mixing costs. However, in the case of algae, the high cost of energy recycling offsets much of the gain [141]. In the case of rapeseed biodiesel, the most increased cost is the effect of food prices and GHG emissions. The cost-effectiveness of biomethane production from three separate sources, including the urban fraction of organic waste, household waste and grass/slurry is analysed [142]. Of the three path, organic fraction of municipal solid waste is the cheapest, followed by slaughterhouse waste, grass and slurry [143]. The price of petroleum-derived transport fuel at service stations, while more expensive, focuses on the biomethane produced from grass and slurry. Biomethane, saves about $85 \%$ of $\mathrm{CO}_{2}$ emissions, which is preferable to liquid fuel [144].

According to the International Energy Agency, the cost of sugar cane ethanol for EU countries is $€ 0.50$ per litre. The cost of corn, sugar beet and wheat ethanol vary from $€ 0.9$ to $€ 1.6$ per litre without subsidies, whereas the price of lignocellulosic ethanol on a pilot scale is around $€ 4.0$ per litre [145]. Currently, animal fat is the cheapest source of biodiesel, while conventional transesterification costs for vegetable oil are currently about $€ 0.4-€ 0.9 / \mathrm{lt}$. New processes are expected to save more costs from economies of scale [146]. Lignocellulose biomass costs more than $€ 0.8 / \mathrm{L}$ for liquid diesel, with possible reductions to $€ 0.6$ $-€ 1.2 / \mathrm{L}$. According to the IEA study (2013), cost of ethanol, conventional biodiesel, and advanced biodiesel are $€ 0.6 / \mathrm{L}, € 1 / \mathrm{L}$ and $€ 1.1 / \mathrm{L}$ respectively [147]. Despite substantial attempts, the cost of biofuels has not decreased dramatically in these years. Developing economies would allow biofuels to compete with fossil fuels in the long term [148]. Hassan and Kalam [149] proposed more optimistic lower cost estimates for second-generation biofuels than conventional biofuels. Borowitzka and Moheimani [150] calculated the cost of the production of algal biodiesel to be between $€ 9-€ 25$ and $€ 15-€ 40$ per gallon in open ponds and photobioreactors, based on a wide range of available reports. This high cost is mainly due to advanced processing techniques of algae. Efroymson et al. [151] indicated that the cost of algal biofuels could be significantly reduced by lowering the number of steps in the processing of algal biofuels, as well as the co-production of a better fraction.

\section{Conclusion}

The present review is to highlight the various biodiesel generation, production, properties, standards, life cycle cost and sustainability assessment. The following are the summary of the analysis:

- First-generation biofuels are almost in decline. Second-generation biofuels which do not displace food production or cause more greenhouse gas emissions are increasingly applied in Europe.

- The third generation of biofuels are having the highest emphasis in the recent years owing to strict environmentally sustainable standards of biofuels.

- The fuel properties and standards for biofuels and Hydrogenated Vegetable Oil have been explored. However, various conversion and upgrading techniques have to be applied to meet the biodiesel standards of EN 14214.

- The requirement of $60 \%$ greenhouse gas savings over the entire life cycle of the fuel including cultivation, processing and transport compared to fossil fuels poses lot of challenges in meeting the current stateof-the-art renewable diesel standards.

- The fourth-generation biofuel are quite fairway in meeting the production costs and performance in engines to consider as serious sustainable fuel.

\section{References}

1 Hama S., Noda H., Kondo A. (2018) How lipase technology contributes to the evolution of biodiesel production using multiple feedstocks, Curr. Opin. Biotechnol. 50, $57-64$.

2 De Oliveira F.C., Coelho S.T. (2017) History, evolution, and environmental impact of biodiesel in Brazil: A review, Renew. Sustain. Energy Rev. 75, 168-179. 
3 Li J., Guo Z. (2017) Structure evolution of synthetic amino acids-derived basic ionic liquids for catalytic production of biodiesel, ACS Sustain. Chem. Eng. 5, 1, 1237-1247.

4 Tian K., Tai K., Chua B.J.W., Li Z. (2017) Directed evolution of Thermomyces lanuginosus lipase to enhance methanol tolerance for efficient production of biodiesel from waste grease, Bioresour. Technol. 245, 1491-1497.

5 Merchan-Merchan W., Abdihamzehkolaei A., MerchanBreuer D.A. (2018) Formation and evolution of carbon particles in coflow diffusion air flames of vaporized biodiesel, diesel and biodiesel-diesel blends, Fuel 226, 263-277.

6 Nogueira L.A., Capaz R.S., Souza S.P., Seabra J.E. (2016) Biodiesel program in Brazil: learning curve over ten years (2005-2015), Biofuels Bioprod. Biorefin. 10, 6, 728-737.

7 Gao Z., Zhu L., Liu C., Li A., He Z., Zhang C., Huang Z. (2017) Comparison of soot formation, evolution, and oxidation reactivity of two biodiesel surrogates, Energy Fuels 31, 8, 8655-8664.

8 Moreno-Pérez O.M., Marcossi G.P., Ortiz-Miranda D. (2017) Taking stock of the evolution of the biodiesel industry in Brazil: Business concentration and structural traits, Energy Policy 110, 525-533.

9 Mahi M.R., Ouaar F., Negadi A., Bahadur I., Negadi L. (2018) Excess/deviation properties of binary mixtures of 2, 5 -dimethylfuran with furfuryl alcohol, methyl isobutyl ketone, 1-butanol and 2-butanol at temperature range of (293.15-323.15) K, Oil \& Gas Sci. Technol. - Rev. IFP Energies nouvelles 73, 64 .

10 Lee S., Lee C.S., Park S., Gupta J.G., Maurya R.K., Agarwal A.K. (2017) Spray characteristics, engine performance and emissions analysis for Karanja biodiesel and its blends, Energy 119, 138-151.

11 Sudhakar K., Anand T., Srivastava T., Premalatha M. (2013) Assessment of carbon mitigation potential of various biofuels in Indian context, Int. J. ChemTech Res. 5, 5, 2456-2461.

12 Zhou J., Xiong Y., Gong Y., Liu X. (2017) Analysis of the oxidative degradation of biodiesel blends using FTIR, UVVis, TGA and TD-DES methods, Fuel 202, 23-28.

13 Chong C.T., Ng J.H., Ahmad S., Rajoo S. (2015) Oxygenated palm biodiesel: Ignition, combustion and emissions quantification in a light-duty diesel engine, Energy Convers. Manage. 101, 317-325.

14 Boutesteijn C., Drabik D., Venus T.J. (2017) The interaction between EU biofuel policy and first-and secondgeneration biodiesel production, Ind. Crops Prod. 106, $124-129$

15 Rahman M.M., Rasul M., Hassan N.M.S. (2017) Study on the tribological characteristics of Australian native first generation and second generation biodiesel fuel, Energies 10, 1,55 .

16 Bahadur S., Goyal P., Sudhakar K., Bijarniya J.P. (2015) A comparative study of ultrasonic and conventional methods of biodiesel production from mahua oil, Biofuels 6, 1-2, 107-113. https://doi.org/10.1080/17597269.2015.1057790.

17 Devarajan Y., Kumar Jayabal R., Ragupathy D., Venu H. (2017) Emissions analysis on second generation biodiesel, Front. Environ. Sci. Eng. 11, 1, 3.

18 Belletante S., Montastruc L., Meyer M., Hermansyah H., Negny S. (2020) Multiproduct biorefinery optimal design: application to the acetone-butanol-ethanol system, Oil Gas Sci. Technol. - Rev. IFP Energies nouvelles 75, 9. https:// doi.org/10.2516/ogst/2020002.
19 Kowalska M., Wegierek-Ciuk A., Brzoska K., Wojewodzka M., Meczynska-Wielgosz S., Gromadzka-Ostrowska J., Mruk R., Øvrevik J., Kruszewski M., Lankoff A. (2017) Genotoxic potential of diesel exhaust particles from the combustion of first-and second-generation biodiesel fuels - The FuelHealth project, Environ. Sci. Pollut. Res. 24, 31, 24223-24234.

20 Sudhakar K., Rajesh M., Premalatha M. (2012) A mathematical model to assess the potential of algal bio-fuels in India, Energy Sources, Part A Recover. Util. Environ. Eff. 34, 12, 1114-1120. https://doi.org/10.1080/15567036. 2011.645121.

21 Zhong W., Xuan T., He Z., Wang Q., Li D., Zhang X., Huang Y.Y. (2016) Experimental study of combustion and emission characteristics of diesel engine with diesel/secondgeneration biodiesel blending fuels, Energy Convers. Manage. 121, 241-250.

22 Erdiwansyah, Mamat R., Sani M.S.M., Sudhakar K., Kadarohman A., Sardjono R.E. (2019) An overview of higher alcohol and biodiesel as alternative fuels in engines, Energy Rep. 5, 467-479. https://doi.org/10.1016/ j.egyr.2019.04.009.

23 Jamaluddin N.A.M., Riayatsyah T.M.I., Silitonga A.S., Mofijur M., Shamsuddin A.H., Ong H.C., Rahman S.M. (2019) Techno-economic analysis and physicochemical properties of Ceiba pentandra as second-generation biodiesel based on ASTM D6751 and EN 14214, Processes 7, 9, 636.

24 Rajak U., Verma T.N. (2020) Influence of combustion and emission characteristics on a compression ignition engine from a different generation of biodiesel, Eng. Sci. Technol. Int. J. 23, 1, 10-20.

25 Bahadur S., Goyal P., Sudhakar K. (2015) Ultrasonic assisted transesterification of neem oil for biodiesel production, Energy Sources Part A Recovery Utilization \& Env. Effects 37, 17, 1921-1927. https://doi.org/10.1080/ 15567036.2014.911783.

26 Ghasemi A., Moosavi-Nasab M. (2020) Production of second-generation biodiesel using low-quality date fruits, Biotechnol. Rep. 27, e00480.

27 Foteinis S., Chatzisymeon E., Litinas A., Tsoutsos T. (2020) Used-cooking-oil biodiesel: Life cycle assessment and comparison with first-and third-generation biofuel, Renew. Energy 153, 588-600.

28 Mofijur M., Rasul M.G., Hassan N.M.S., Nabi M.N. (2019) Recent development in the production of third generation biodiesel from microalgae, Energy Procedia 156, 53-58.

29 Zhang Z., Bi G., Zhang H., Zhang A., Li X., Xie J. (2019) Highly active and selective hydrodeoxygenation of oleic acid to second generation bio-diesel over $\mathrm{SiO}_{2}$-supported $\mathrm{Co}_{\mathrm{x}-}$ $\mathrm{Ni}_{1-\mathrm{x}} \mathrm{P}$ catalysts, Fuel 247, 26-35.

30 Mofijur M., Siddiki S.Y.A., Ahmed M.B., Djavanroodi F., Fattah I.R., Ong H.C., Mahlia T.M.I. (2020) Effect of nanocatalysts on the transesterification reaction of first, second and third generation biodiesel sources - A minireview, Chemosphere, 128642.

31 Kamil M., Ramadan K., Ghenai C., Olabi A.G., Nazzal I.T. (2019) Emissions from combustion of second-generation biodiesel produced from seeds of date palm fruit (Phoenix dactylifera L.), Appl. Sci. 9, 18, 3720.

32 Boopathi D., Thiyagarajan S., Edwin Geo V., Madhankumar S. (2020) Effect of the second generation and third generation biofuel blend on performance, emission and combustion characteristics of CI engine, Int. J. Ambient Energy 41, 7, 767-774. 
33 Singh D., Sharma D., Soni S.L., Sharma S., Sharma P.K., Jhalani A. (2020) A review on feedstocks, production processes, and yield for different generations of biodiesel, Fuel 262, 116553.

34 Abdullah B., Muhammad S.A.F.A.S., Shokravi Z., Ismail S., Kassim K.A., Mahmood A.N., Aziz M.M.A. (2019) Fourth generation biofuel: A review on risks and mitigation strategies, Renew. Sustain. Energy Rev. 107, 37-50.

35 Dutta K., Daverey A., Lin J.G. (2014) Evolution retrospective for alternative fuels: First to fourth generation, Renew. Energy 69, 114-122.

36 Mat Aron N.S., Khoo K.S., Chew K.W., Show P.L., Chen W.H., Nguyen T.H.P. (2020) Sustainability of the four generations of biofuels-A review, Int. J. Energy Res. 44, 12, 9266-9282.

37 Shokravi Z., Shokravi H., Aziz M.M.A., Shokravi H. (2019) The Fourth-Generation Biofuel: A Systematic Review on Nearly Two Decades of Research from 2008 to 2019, in: Aziz Md Maniruzzaman Bin A. (ed), Fossil free fuels trends renewable energy, Taylor and Francis, London.

38 Moravvej Z., Makarem M.A., Rahimpour M.R. (2019) The fourth generation of biofuel, in: Second and third generation of feedstocks, Elsevier, Netherland, pp. 557-597.

39 Alalwan H.A., Alminshid A.H., Aljaafari H.A. (2019) Promising evolution of biofuel generations. Subject review, Renew. Energy Focus 28, 127-139.

40 Oliveira L.E., Cedeno R.F., Chavez E.G., Gelli V.C., Masarin F. (2019) Red macroalgae kappaphycus alvarezii as feedstock for nutraceuticals, pharmaceuticals and fourth generation biofuel production, Red 17, 546-549.

41 Chowdhury H., Loganathan B. (2019) Third-generation biofuels from microalgae: a review, Curr. Opin. Green Sustain. Chem. 20, 39-44.

42 Chowdhury H., Loganathan B., Mustary I., Alam F., Mobin S.M. (2019) Algae for biofuels: The third generation of feedstock, in: Second and third generation of feedstocks, Elsevier, Netherland, pp. 323-344.

43 Nagler A., Gerace S. (2020) First and second generation biofuels, Fuel 6, 12.

44 Boboescu I.Z., Chemarin F., Beigbeder J.B., de Vasconcelos B.R., Munirathinam R., Ghislain T., Lavoie J.M. (2019) Making next-generation biofuels and biocommodities a feasible reality, Curr. Opin. Green Sustain. Chem. 20, 25-32.

$45 \mathrm{Wu}$ Y., Ferns J., Li H., Andrews G. (2017) Investigation of combustion and emission performance of hydrogenated vegetable oil (HVO) diesel, SAE Int. J. Fuels Lubr. 10, 3, 895-903.

46 Gottschalk P., Brodesser B., Poncelet D., Jaeger H., Rennhofer H., Cole S. (2018) Formation of essential oil containing microparticles comprising a hydrogenated vegetable oil matrix and characterisation thereof, J. Microencapsulation. 35, 6, 513-521.

47 Bezergianni S., Dimitriadis A. (2013) Comparison between different types of renewable diesel, Renew. Sustain. Energy Rev. 21, 110-116.

48 Hamdan S.H., Chong W.W.F., Ng J.H., Ghazali M., Wood R.J.K. (2017) Influence of fatty acid methyl ester composition on tribological properties of vegetable oils and duck fat derived biodiesel, Tribol. Int. 113, 76-82.

49 Vargas-Bello-Pérez E., Fehrmann-Cartes K., ÍñiguezGonzález G., Toro-Mujica P., Garnsworthy P.C. (2015) Chemical composition, fatty acid composition, and sensory characteristics of Chanco cheese from dairy cows supplemented with soybean and hydrogenated vegetable oils, J. Dairy Sci. 98, 1, 111-117.

50 Zupanič N., Hribar M., Pivk Kupirovič U., Kušar A., Žmitek K., Pravst I. (2018) Limiting trans fats in foods: Use of partially hydrogenated vegetable oils in prepacked foods in Slovenia, Nutrients 10, 3, 355.

51 Ramírez-Gómez N.O., Acevedo N.C., Toro-Vázquez J.F., Ornelas-Paz J.J., Dibildox-Alvarado E., Pérez-Martínez J.D. (2016) Phase behavior, structure and rheology of candelilla wax/fully hydrogenated soybean oil mixtures with and without vegetable oil, Food Res. Int. 89, 828-837.

52 Kubant R., Poon A.N., Sánchez-Hernández D., Domenichiello A.F., Huot P.S.P., Pannia E., Anderson G. H. (2015) A comparison of effects of lard and hydrogenated vegetable shortening on the development of high-fat dietinduced obesity in rats, Nutr. Diab. 5, 12, e188-e188.

53 Domínguez-Barroso M.V., Herrera C., Larrubia M.A., Alemany L.J. (2016) Diesel oil-like hydrocarbon production from vegetable oil in a single process over $\mathrm{Pt}-\mathrm{Ni} / \mathrm{Al}_{2} \mathrm{O}_{3}$ and $\mathrm{Pd} / \mathrm{C}$ combined catalysts, Fuel Process. Technol. 148, 110-116.

54 Manchanda T., Tyagi R., Sharma D.K. (2018) Comparison of fuel characteristics of green (renewable) diesel with biodiesel obtainable from algal oil and vegetable oil, Energy Sources Part A Recovery Utilization \& Env. Effects 40, 1, 54-59.

55 Yoshinaga K., Kawamura Y., Kitayama T., Nagai T., Mizobe H., Kojima K., Gotoh N. (2015) Regiospecific distribution of trans-octadecenoic acid positional isomers in triacylglycerols of partially hydrogenated vegetable oil and ruminant fat, J. Oleo Sci. 64, 6, 617-624.

56 Glisic S.B., Pajnik J.M., Orlović A.M. (2016) Process and techno-economic analysis of green diesel production from waste vegetable oil and the comparison with ester type biodiesel production, Appl. Energy 170, 176-185.

57 Delmonte P. (2016) Evaluation of poly (90\% biscyanopropyl/ $10 \%$ cyanopropylphenyl siloxane) capillary columns for the gas chromatographic quantification of trans fatty acids in non-hydrogenated vegetable oils, J. Chromatogr. A 1460, 160-172.

58 Dohnalova L., Bucek P., Vobornik P., Dohnal V. (2017) Determination of nickel in hydrogenated fats and selected chocolate bars in Czech Republic, Food Chem. 217, 456-460.

59 Pechout M., Kotek M., Jindra P., Macoun D., Hart J., Vojtisek-Lom M. (2019) Comparison of hydrogenated vegetable oil and biodiesel effects on combustion, unregulated and regulated gaseous pollutants and DPF regeneration procedure in a Euro6 car, Sci. Total Env. 696, 133748.

60 Nordelöf A., Romare M., Tivander J. (2019) Life cycle assessment of city buses powered by electricity, hydrogenated vegetable oil or diesel, Transp. Res. Part D Transp. Env. 75, 211-222.

61 Krivopolianskii V., Bjørgen K.O.P., Emberson D., Ushakov S., Æsøy V., Løvås T. (2019) Experimental study of ignition delay, combustion, and NO emission characteristics of hydrogenated vegetable oil, SAE Int. J. Fuels Lubr. 12, 04-12-01-0002, 29-42.

62 Adu-Mensah D., Mei D., Zuo L., Zhang Q., Wang J. (2019) A review on partial hydrogenation of biodiesel and its influence on fuel properties, Fuel 251, 660-668.

63 Rajkumar S., Thangaraja J. (2019) Effect of biodiesel, biodiesel binary blends, hydrogenated biodiesel and injection parameters on $\mathrm{NO}_{\mathrm{x}}$ and soot emissions in a turbocharged diesel engine, Fuel 240, 101-118. 
64 Pachiannan T., Zhong W., Xuan T., Li B., He Z., Wang Q., Yu X. (2019) Simultaneous study on spray liquid length, ignition and combustion characteristics of diesel and hydrogenated catalytic biodiesel in a constant volume combustion chamber, Renew. Energy 140, 761-771.

65 Singh D., Sharma D., Soni S.L., Sharma S., Kumari D. (2019) Chemical compositions, properties, and standards for different generation biodiesels: A review, Fuel 253, 60-71.

66 Deshmukh S., Kumar R., Bala K. (2019) Microalgae biodiesel: A review on oil extraction, fatty acid composition, properties and effect on engine performance and emissions, Fuel Process. Technol. 191, 232-247.

67 Rezania S., Oryani B., Park J., Hashemi B., Yadav K.K., Kwon E.E., Cho J. (2019) Review on transesterification of non-edible sources for biodiesel production with a focus on economic aspects, fuel properties and by-product applications, Energy Convers. Manage. 201, 112155.

68 Karthickeyan V. (2019) Effect of cetane enhancer on Moringa oleifera biodiesel in a thermal coated direct injection diesel engine, Fuel 235, 538-550.

69 Nogales-Delgado S., Encinar J.M., Guiberteau A., Márquez S. (2020) The effect of antioxidants on corn and sunflower biodiesel properties under extreme oxidation conditions, J. Am. Oil Chem. Soc. 97, 2, 201-212.

70 Seffati K., Honarvar B., Esmaeili H., Esfandiari N. (2019) Enhanced biodiesel production from chicken fat using $\mathrm{CaO} /$ $\mathrm{CuFe}_{2} \mathrm{O}_{4}$ nanocatalyst and its combination with diesel to improve fuel properties, Fuel 235, 1238-1244.

71 Gurusamy S., Kulanthaisamy M.R., Hari D.G., Veleeswaran A., Thulasinathan B., Muthuramalingam J.B., Balasubramani R., Chang S.W., Arasu M.V., AlDhabi N.A., Selvaraj A. (2019) Environmental friendly synthesis of $\mathrm{TiO}_{2}-\mathrm{ZnO}$ nanocomposite catalyst and silver nanomaterials for the enhanced production of biodiesel from Ulva lactuca seaweed and potential antimicrobial properties against the microbial pathogens, J. Photochem. Photobiol. B: Biol. 193, 118-130.

72 Chammoun N., Geller D.P., Das K.C. (2013) Fuel properties, performance testing and economic feasibility of Raphanus sativus (oilseed radish) biodiesel, Ind. Crops Prod. 45, 155-159.

73 Mahlia T.M.I., Syazmi Z.A.H.S., Mofijur M., Abas A.P., Bilad M.R., Ong H.C., Silitonga A.S. (2020) Patent landscape review on biodiesel production: Technology updates, Renew. Sustain. Energy Rev. 118, 109526.

74 Deshmukh S., Bala K., Kumar R. (2019) Selection of microalgae species based on their lipid content, fatty acid profile and apparent fuel properties for biodiesel production, Env. Sci. Pollut. Res. 26, 24, 24462-24473.

75 Nouri H., Moghimi H., Rad M.N., Ostovar M., Mehr S.S.F., Ghanaatian F., Talebi A.F. (2019) Enhanced growth and lipid production in oleaginous fungus, Sarocladium kiliense ADH17: Study on fatty acid profiling and prediction of biodiesel properties, Renew. Energy 135, 10-20.

76 Ong H.C., Mofijur M., Silitonga A.S., Gumilang D., Kusumo F., Mahlia T.M.I. (2020) Physicochemical properties of biodiesel synthesised from grape seed, philippine tung, kesambi, and palm oils, Energies 13, 6, 1319.

77 Sia C.B., Kansedo J., Tan Y.H., Lee K.T. (2020) Evaluation on biodiesel cold flow properties, oxidative stability and enhancement strategies: A review, Biocatal. Agric. Biotechnol. 24, 101514.
78 Trivedi T., Jain D., Mulla N.S., Mamatha S.S., Damare S. R., Sreepada R.A., Kumar S., Gupta V. (2019) Improvement in biomass, lipid production and biodiesel properties of a euryhaline Chlorella vulgaris NIOCCV on mixotrophic cultivation in wastewater from a fish processing plant, Renew. Energy 139, 326-335.

79 Zöldy M. (2020) Fuel properties of butanol-hydrogenated vegetable oil blends as a diesel extender option for internal combustion engines, Period. Polytech. Chem. Eng. 64, 2, 205-212.

80 Adu-Mensah D., Mei D., Zuo L., Zhang Q., Wang J. (2019) A review on partial hydrogenation of biodiesel and its influence on fuel properties, Fuel 251, 660-668.

81 Šimáček P., Souček I., Pospíšil M., Vrtiška D., Kittel H. (2019) Impact of hydrotreated vegetable oil and biodiesel on properties in blends with mineral diesel fuel, Therm. Sci. 00, 315-315.

82 Dobrzyńska E., Szewczyńska M., Pośniak M., Szczotka A., Puchaõõlka B., Woodburn J. (2020) Exhaust emissions from diesel engines fueled by different blends with the addition of nanomodifiers and hydrotreated vegetable oil HVO, Env. Pollut. 259, 113772.

83 Eller Z., Varga Z., Hancsók J. (2019) Renewable jet fuel from kerosene/coconut oil mixtures with catalytic hydrogenation, Energy Fuels 33, 7, 6444-6453.

84 Raza M.Q., Arshad M.U., Arshad M.S., Anjum F.M., Imran A., Ahmed A., Munir H. (2020) Consequences of hydrogenated vegetable fat substitution with Ajwa seed oil on physicochemical and nutritional aspects of functional cookies, Food Sci. Nutr. 8, 3, 1365-1374.

85 Albrand P., Julcour C., Gerbaud V., Billet A.M. (2020) Accurate hydrogenated vegetable oil viscosity predictions for monolith reactor simulations, Chem. Eng. Sci. 214, 115388.

86 Rodríguez-Fernández J., Hernández J.J., Calle-Asensio A., Ramos Á., Barba J. (2019) Selection of blends of diesel fuel and advanced biofuels based on their physical and thermochemical properties, Energies 12, 11, 2034.

87 Vargas-Bello-Pérez E., Loor J.J., Garnsworthy P.C. (2020) Fatty acid transport in plasma from cows treated with ruminal pulses of fish oil and partially hydrogenated vegetable oil, Livest. Sci. 236, 104018.

88 McCaffery C., Karavalakis G., Durbin T., Jung H., Johnson K. (2020) Engine-out emissions characteristics of a light duty vehicle operating on a hydrogenated vegetable oil renewable diesel. SAE Technical Paper 2020-01-033\%. https://doi.org/10.4271/2020-01-0337.

89 Kabir H., Zhu H., May J., Hamal K., Kan Y., Williams T., Pandhi T. (2019) The $\mathrm{sp}^{2}-\mathrm{sp}^{3}$ carbon hybridization content of nanocrystalline graphite from pyrolyzed vegetable oil, comparison of electrochemistry and physical properties with other carbon forms and allotropes, Carbon 144, 831-840.

90 Sonthalia A., Kumar N. (2019) Hydroprocessed vegetable oil as a fuel for transportation sector: A review, J. Energy Inst. 92, 1, 1-17.

91 Konne J.L., Onobun J.D. (2020) Production of biodiesel from dacryodes edulis seeds oil using green $\mathrm{ZnO}$ and hydrogenated $\mathrm{ZnO}$ catalysts, J. Chem. Soc. Nigeria 45, 2, 259-264.

92 Mathew B.C., Thangaraja J., Sivaramakrishna A. (2019) Combustion, performance and emission characteristics of blends of methyl esters and modified methyl esters of karanja and waste cooking oil on a turbocharged CRDI engine, Clean Technol. Env. Policy 21, 9, 1791-1807. 
93 Dujjanutat P., Kaewkannetra P. (2020) Production of biohydrogenated kerosene by catalytic hydrocracking from refined bleached deodorised palm/palm kernel oils, Renew. Energy 147, 464-472.

94 Sindhu R., Binod P., Pandey A., Ankaram S., Duan Y., Awasthi M.K. (2019) Biofuel production from biomass: Toward sustainable development, in: Current developments in biotechnology and bioengineering, Elsevier, London, pp. 79-92.

95 Fazal M.A., Rubaiee S., Al-Zahrani A. (2019) Overview of the interactions between automotive materials and biodiesel obtained from different feedstocks, Fuel Process. Technol. 196, 106178 .

96 Sundus F., Fazal M.A., Masjuki H.H. (2017) Tribology with biodiesel: A study on enhancing biodiesel stability and its fuel properties, Renew. Sustain. Energy Rev. 70, 399-412.

97 Hari T.K., Yaakob Z., Binitha N.N. (2015) Aviation biofuel from renewable resources: Routes, opportunities and challenges, Renew. Sustain. Energy Rev. 42, 1234-1244.

98 Su Y., Zhang P., Su Y. (2015) An overview of biofuels policies and industrialization in the major biofuel producing countries, Renew. Sustain. Energy Rev. 50, 991-1003.

99 Cremonez P.A., Feroldi M., de Oliveira C.D.J., Teleken J. G., Alves H.J., Sampaio S.C. (2015) Environmental, economic and social impact of aviation biofuel production in Brazil, New Biotechnol. 32, 2, 263-271.

100 Ben-Iwo J., Manovic V., Longhurst P. (2016) Biomass resources and biofuels potential for the production of transportation fuels in Nigeria, Renew. Sustain. Energy Rev. 63, 172-192.

101 Anuar M.R., Abdullah A.Z. (2016) Challenges in biodiesel industry with regards to feedstock, environmental, social and sustainability issues: A critical review, Renew. Sustain. Energy Rev. 58, 208-223.

102 Efroymson R.A., Dale V.H. (2015) Environmental indicators for sustainable production of algal biofuels, Ecol. Indic. 49, 1-13.

103 Kan T., Strezov V., Evans T. (2016) Effect of the heating rate on the thermochemical behavior and biofuel properties of sewage sludge pyrolysis, Energy Fuels 30, 3, 1564-1570.

104 Gnanasekaran S., Saravanan N., Ilangkumaran M. (2016) Influence of injection timing on performance, emission and combustion characteristics of a DI diesel engine running on fish oil biodiesel, Energy 116, 1218-1229.

105 Gaurav A., Ng F.T., Rempel G.L. (2016) A new green process for biodiesel production from waste oils via catalytic distillation using a solid acid catalyst - Modeling, economic and environmental analysis, Green Energy Env. $\mathbf{1}, 1,62-74$.

106 Joshi G., Pandey J.K., Rana S., Rawat D.S. (2017) Challenges and opportunities for the application of biofuel, Renew. Sustain. Energy Rev. 79, 850-866.

107 Caliskan H. (2017) Environmental and enviroeconomic researches on diesel engines with diesel and biodiesel fuels, J. Clean. Prod. 154, 125-129.

108 Alam F., Mobin S., Chowdhury H. (2015) Third generation biofuel from Algae, Procedia Eng. 105, 763-768.

109 Farooq M., Ramli A., Naeem A. (2015) Biodiesel production from low FFA waste cooking oil using heterogeneous catalyst derived from chicken bones, Renew. Energy 76, 362-368.

110 Vassilev S.V., Vassileva C.G. (2016) Composition, properties and challenges of algae biomass for biofuel application: An overview, Fuel 181, 1-33.
111 Hasan M.M., Rahman M.M. (2017) Performance and emission characteristics of biodiesel-diesel blend and environmental and economic impacts of biodiesel production: A review, Renew. Sustain. Energy Rev. 74, 938-948.

112 Dickinson S., Mientus M., Frey D., Amini-Hajibashi A., Ozturk S., Shaikh F., Sengupta D., El-Halwagi M.M. (2017) A review of biodiesel production from microalgae, Clean Technol. Env. Policy 19, 3, 637-668.

113 Gaurav N., Sivasankari S., Kiran G.S., Ninawe A., Selvin J. (2017) Utilization of bioresources for sustainable biofuels: A review, Renew. Sustain. Energy Rev. 73, 205-214.

114 Robertson G.P., Hamilton S.K., Barham B.L., Dale B.E., Izaurralde R.C., Jackson R.D., Landis D.A., Swinton S.M., Thelen K.D., Tiedje J.M. (2017) Cellulosic biofuel contributions to a sustainable energy future: Choices and outcomes, Science 356, 6345, 938-948.

115 Yadava S., Maitra S.S. (2017) Molecular detection of Methylotrophs from an Indian landfill site and their potential for biofuel production, Glob. Nest J. 19, 3, 533-539.

116 Dash S.K., Lingfa P. (2017) A review on production of biodiesel using catalyzed transesterification, in: AIP Conference Proceedings (Vol. 1859, No. 1), AIP Publishing LLC, USA, 020100 p.

117 Boonrod B., Prapainainar C., Narataruksa P., Kantama A., Saibautrong W., Sudsakorn K., Mungcharoen T., Prapainainar P. (2017) Evaluating the environmental impacts of bio-hydrogenated diesel production from palm oil and fatty acid methyl ester through life cycle assessment, $J$. Clean. Prod. 142, 1210-1221.

118 Pragya N., Pandey K.K. (2016) Life cycle assessment of green diesel production from microalgae, Renew. Energy $\mathbf{8 6}$, 623-632.

119 Capaz R.S., Seabra J.E.A. (2016) Life cycle assessment of biojet fuels, in: Biofuels for aviation, Academic Press, USA, pp. $279-294$.

120 Rajaeifar M.A., Akram A., Ghobadian B., Rafiee S., Heijungs R., Tabatabaei M. (2016) Environmental impact assessment of olive pomace oil biodiesel production and consumption: A comparative lifecycle assessment, Energy 106, 87-102.

121 Matzen M., Demirel Y. (2016) Methanol and dimethyl ether from renewable hydrogen and carbon dioxide: Alternative fuels production and life-cycle assessment, J. Clean. Prod. 139, 1068-1077.

122 Wong A.J. (2016) Life cycle assessment of lignocellulosic biomass conversion pathways to hydrogenation derived renewable diesel, Int. J. Life Cycle Assess. 21, 10, 1404-1424.

123 Rajaeifar M.A., Abdi R., Tabatabaei M. (2017) Expanded polystyrene waste application for improving biodiesel environmental performance parameters from life cycle assessment point of view, Renew. Sustain. Energy Rev. 74, 278-298.

124 Glisic S.B., Pajnik J.M., Orlović A.M. (2016) Process and techno-economic analysis of green diesel production from waste vegetable oil and the comparison with ester type biodiesel production, Appl. Energy 170, 176-185.

125 Mahbub N., Oyedun A.O., Kumar A., Oestreich D., Arnold U., Sauer J. (2017) A life cycle assessment of oxymethylene ether synthesis from biomass-derived syngas as a diesel additive, J. Clean. Prod. 165, 1249-1262.

126 Wong A., Zhang H., Kumar A. (2016) Life cycle water footprint of hydrogenation-derived renewable diesel production from lignocellulosic biomass, Water Res. 102, $330-345$ 
127 Yang J., Fujiwara T., Geng Q. (2017) Life cycle assessment of biodiesel fuel production from waste cooking oil in Okayama City, J. Mater. Cycles Waste Manage. 19, 4, 1457-1467.

128 Wong A., Zhang H., Kumar A. (2016) Life cycle assessment of renewable diesel production from lignocellulosic biomass, Int. J. Life Cycle Assess. 21, 10, 1404-1424.

129 Zhou H., Qian Y., Kraslawski A., Yang Q., Yang S. (2017) Life-cycle assessment of alternative liquid fuels production in China, Energy 139, 507-522.

130 Vahidi E., Zhao F. (2017) Environmental life cycle assessment on the separation of rare earth oxides through solvent extraction, J. Env. Manage. 203, 255-263.

131 Sorunmu Y.E., Billen P., Elkasabi Y., Mullen C.A., Macken N.A., Boateng A.A., Spatari S. (2017) Fuels and chemicals from equine-waste-derived tail gas reactive pyrolysis oil: technoeconomic analysis, environmental and exergetic life cycle assessment, ACS Sustain. Chem. Eng. 5, 10, 8804-8814.

132 Portugal-Pereira J., Nakatani J., Kurisu K., Hanaki K. (2016) Life cycle assessment of conventional and optimised Jatropha biodiesel fuels, Renew. Energy 86, 585-593.

$133 \mathrm{Wu}$ Y., Ferns J., Li H., Andrews G. (2017) Investigation of combustion and emission performance of hydrogenated vegetable oil (HVO) diesel, SAE Int. J. Fuels Lubr. 10, 3, 895-903.

134 Hari T.K., Yaakob Z., Binitha N.N. (2015) Aviation biofuel from renewable resources: Routes, opportunities and challenges, Renew. Sustain. Energy Rev. 42, 1234-1244.

$135 \mathrm{Su}$ Y., Zhang P., Su Y. (2015) An overview of biofuels policies and industrialization in the major biofuel producing countries, Renew. Sustain. Energy Rev. 50, 991-1003.

136 Mukherjee I., Sovacool B.K. (2014) Palm oil-based biofuels and sustainability in southeast Asia: A review of Indonesia, Malaysia, and Thailand, Renew. Sustain. Energy Rev. 37, $1-12$.

137 Gashaw A., Teshita A. (2014) Production of biodiesel from waste cooking oil and factors affecting its formation: A review, Int. J. Renew. Sustain. Energy 3, 5, 92-98.

138 Cremonez P.A., Feroldi M., de Oliveira C.D.J., Teleken J. G., Alves H.J., Sampaio S.C. (2015) Environmental, economic and social impact of aviation biofuel production in Brazil, New Biotechnol. 32, 2, 263-271.
139 Efroymson R.A., Dale V.H. (2015) Environmental indicators for sustainable production of algal biofuels, Ecol. Indic. 49, 1-13.

140 Datta A., Mandal B.K. (2014) Use of Jatropha biodiesel as a future sustainable fuel, Energy Technol. Policy 1, 1, 8-14.

141 van Eijck J., Romijn H., Smeets E., Bailis R., Rooijakkers M., Hooijkaas N., Verweij P., Faaij A. (2014) Comparative analysis of key socio-economic and environmental impacts of smallholder and plantation based jatropha biofuel production systems in Tanzania, Biomass Bioenergy 61, 25-45.

142 Alam F., Mobin S., Chowdhury H. (2015) Third generation biofuel from Algae, Procedia Eng. 105, 763-768.

143 Ho D.P., Ngo H.H., Guo W. (2014) A mini review on renewable sources for biofuel, Bioresour. Technol. 169, $742-749$.

144 Kumar S., Shrestha P., Salam P.A. (2013) A review of biofuel policies in the major biofuel producing countries of ASEAN: Production, targets, policy drivers and impacts, Renew. Sustain. Energy Rev. 26, 822-836.

145 Salvi B.L., Panwar N.L. (2012) Biodiesel resources and production technologies - A review, Renew. Sustain. Energy Rev. 16, 6, 3680-3689.

146 Milazzo M.F., Spina F., Cavallaro S., Bart J.C.J. (2013) Sustainable soy biodiesel, Renew. Sustain. Energy Rev. 27, 806-852.

147 Silalertruksa T., Gheewala S.H. (2012) Environmental sustainability assessment of palm biodiesel production in Thailand, Energy 43, 1, 306-314.

148 Obidzinski K., Andriani R., Komarudin H., Andrianto A. (2012) Environmental and social impacts of oil palm plantations and their implications for biofuel production in Indonesia, Ecol. Soc. 17, 1, 25.

149 Hassan M.H., Kalam M.A. (2013) An overview of biofuel as a renewable energy source: Development and challenges, Procedia Eng. 56, 39, 53.

150 Borowitzka M.A., Moheimani N.R. (2013) Sustainable biofuels from algae, Mitig. Adapt. Strat. Glob. Chang. 18, $1,13-25$.

151 Efroymson R.A., Dale V.H., Kline K.L., McBride A.C., Bielicki J.M., Smith R.L., Parish E.S., Schweizer P.E., Shaw D.M. (2013) Environmental indicators of biofuel sustainability: What about context? Env. Manage. 51, 2, 291-306. 